\title{
The Slow and Lonesome Death of the Arbitration Convention
}

\author{
Fred C. de Hosson, Baker \& McKenzie, Amsterdam
}

The lack of direct-tax harmonization within the European Union remains one of the primary obstacles to the creation of a truly Internal Market for enterprises. In the area of corporate income tax, the complex problems inherent in the cross-border effects of imputation systems, offset of losses, allocation of financing costs etc. often form those obstacles. There is, however, one problem whose cause is easy to identify but appears to defy elimination. The cause lies in the violation of the generally accepted principle that the income of an enterprise should not be taxed twice. As obvious as this principle is - particularly within an Internal Market - it is persistently difficult to apply.

To start with, the familiar arm's length maxim for determining how business income is allocated is at odds with the objectives of the Internal Market, which should allow an enterprise to operate on the internal market as an integrated whole rather than as a group of unaffiliated entities. On top of that, over the past decade, a number of Member States have let loose a torrent of detailed transfer-pricing and documentation regulations in an effort to secure a 'fair share of the cake'. The sheer expense involved in consulting with the various tax authorities about the substance of the regulations and adherence to the compliance rules prevents the Internal Market from offering the efficiency of a truly integrated market of a federal state such as the US. Moreover, in spite of (or because of?) these rules and regulations, Member States regularly fail to agree on how to apply the profit allocation rules in their bilateral treaties (Arts. 7 and 9 of the OECD Model). In such cases, the risk of double taxation is real. On the basis of the bilateral treaty network of the Member States, the competent authority consultation procedure can provide a solution, but there are no guarantees. Unfortunately, it is not unusual for tax authorities to refrain from pulling out all the stops to come up with solutions unless a company is prepared to 'settle' other - completely unrelated - pending tax problems to their satisfaction. Obviously, this is an intolerable situation in a single market.

Accepted in 1990, the multilateral Arbitration Convention, which provided for binding arbitration as an ultimate remedy, was the very least that could be done to put an end to the situation. Ratification of the Convention was a long time coming. It finally entered into force in January 1995, but only after the 1992 Ruding Report identified transfer pricing as one of the most important areas for the Internal Market. Although to date only one case has come up for arbitration (a 1997 case between France and Italy), the Convention has served its purpose. Tax authorities involved in transfer pricing cases knew they had to come up with the goods, because taxpayers could rely on binding arbitration in the end.

And now a truly embarrassing development has taken place: the Convention expired in 2000 and a number of Member States (Greece, Italy, Ireland, Portugal and Sweden) have still not ratified the prolongation protocol of May 1999 and it is uncertain whether they ever will. The Convention, unloved by its parents, seems to be awaiting a slow and lonesome death.

There is some talk about an arbitration directive. This is an ironic development since the arbitration initiative was originally presented as a directive but, in an effort to keep it outside the jurisdiction of the ECJ, it was adopted as a multilateral convention between the Member States. The Member States have since discovered that this was perhaps not such a good idea: the interpretation of the Convention's provisions is a major problem and the Court is not in a position to play referee. It is, however, highly questionable whether the Member States who are reluctant to ratify the prolongation protocol would be willing to sign up to a directive.

Where Member States fail, the Court has frequently stepped in to advance the development of the Internal Market. The EC Treaty (Art. 293) requires Member States 'so far as is necessary (to) enter into negotiations with each other with a view to securing for the benefit of their nationals ... the abolition of double taxation within the Community'. The Court held in Mutsch, $137 / 84$, that the Article is not intended to confer on taxpayers any rights that they might be able to rely on before their national courts. It merely indicates that Member States should negotiate with each other in order to abolish double taxation within the Community. The Arbitration Convention was based on this provision and would indeed have achieved that objective.

Now that the Convention is all but dead, it is time to examine the effect of bilateral tax treaties that aim to prevent double taxation. Although in the past a few authors have suggested that Member States no longer have the power to conclude treaties of this kind, the Court clearly has a different view. 
In Gilly, C-336/96, the Court noted that the Member States remain competent to 'define the criteria for allocating their powers of taxation as between themselves, with a view to eliminating double taxation', and in doing so 'it is (not) unreasonable for the Member States to base their agreements on international practice and the Model Convention drawn up by the OECD .... The Court repeated this judgment in Saint Gobain, C-307/97 but added an intriguing paragraph (57): 'As far as the exercise of the power of taxation so allocated is concerned, the Member States nevertheless may not disregard Community rules. According to the settled case-law of the Court, although taxation is a matter for the Member States, they must nevertheless exercise their taxation powers consistently with Community law'.

What the Court seems to be saying here is that when two Member States conclude a bilateral tax treaty the results must comply with EC law. Double taxation of business income would clearly violate EC law since it acts as a barrier and makes exercising the fundamental freedom of establishment enshrined in Arts. 43 and 48 of the EC Treaty less attractive. I submit that if Member States have concluded a bilateral tax treaty based on the OECD Model, but fail to reach agreement on the application of Art. 7 (Business Income) and Art. 9 (Associated Enterprises) in a particular case, the Court would decide that the ensuing double taxation is in breach of primary Community law: the freedom of establishment. In that event, the Court might order the Member States involved (or advise the judiciary of these Member States) to find a way to eliminate this infringement. Binding arbitration would just fit the bill. 